\title{
Cell block sensitivity for immunohistochemical detection of cytokeratin 5, oestrogen and progesterone receptors in canine primary mammary carcinoma
}

\author{
Tatiane L. Silveira ${ }^{\mathrm{a}}$, Luciana M. Campos ${ }^{\mathrm{b}}$, Rozany M. Dufloth ${ }^{\mathrm{a}, \mathrm{d}}$, Helio A. Miot ${ }^{\mathrm{a}}$, \\ Haline B. Fêo ${ }^{b}$, Luis M. Montoya ${ }^{b, c^{*}}$, Noeme S. Rocha ${ }^{a, b}$
}

\begin{abstract}
Mammary carcinomas are relatively common ailments among female canines aged around 10 years old, presenting an important morbidity with an average survival of five years. The cytoinclusion technique is frequently employed in human medicine as the investigative method of choice as it quickly provides resources for the determination of the correct therapeutic response, however, the effectiveness of the technique in canines remains understudied in veterinary medicine. This study aims at evaluating the degree of correlation with immunohistochemical marking for cytokeratin 5 (CK5), oestrogen and progesterone receptors (ER and PR) between the cytoinclusion and the histopathology technique in mammary carcinomas. Twenty-five samples of mammary carcinoma, both for the cytoinclusion and histopathological techniques were submitted for histological processing; microscope slides were created for hematoxylin-eosin (HE) staining and the immunohistochemical technique (IHC) was assessed for the ER, PR and CK5 receptors. Through the HE staining, we reached a concordance rate of $100 \%$ between the cytoinclusion and the histopathological analysis in the diagnosis of carcinomas. The immunohistochemical assay presented sensitivity of $85.71 \%, 95.45 \%$ and $100 \%$ and Cohen's kappa of $0.78,0.84$ and 0.95 for ER, PR and CK5, respectively, as well as $100 \%$ specificity and $P<0.01$ for all three markers. Therefore, cytoinclusion represents an accessible, fast and low-cost method, offering high sensitivity for the cytomorphological and immunohistochemical diagnosis of mammary carcinoma in female canines.
\end{abstract}

Key words: cytoinclusion, histopathological, immunohistochemistry, tumor.

RESUMEN. Los carcinomas mamarios son relativamente comunes en hembras caninas con edades de alrededor 10 años y representan un importante factor de morbilidad para estas hembras; la técnica de citoinclusión es frecuentemente empleada en medicina humana como un método de diagnóstico que permite proveer información rápida para la determinación de una conducta terapéutica correcta, sin embargo, la efectividad de esta técnica permanece poco estudiada en medicina veterinaria. El objetivo del estudio fue evaluar el grado de correlación entre marcadores inmunohistoquímicos para citokeratina 5 (CK5), receptores de estrógenos y progesterona (RE y RP) entre la técnica de citoinclusión y la técnica histopatológica en carcinoma mamario. Veinticinco muestras de carcinoma mamario para la técnica de citoinclusión e histopatológica fueron sometidas a procesamiento histológico, láminas fueron confeccionadas para la tinción mediante hematoxilina y eosina (HE), y la técnica de inmunohistoquímica para identificar la expresión de RE, RP y CK5. Mediante la tinción de la HE fue encontrado una proporción de concordancia del 100\% entre el análisis de citoinclusión e histopatológico de carcinoma mamario. El análisis inmunohistoquímico evidenció una sensibilidad del $85,71 \%, 95,45 \%$ y $100 \%$ y un índice kappa de Cohen de 0,78, 0,84 y 0,95 para RE, RP y CK5, respectivamente, así como $100 \%$ de especificidad $P<0,01$ en todos los marcadores. De esta forma, la citoinclusión representa un método rápido, accesible y de bajo costo, que ofrece alta sensibilidad para el diagnóstico citomorfológico e inmunohistoquímico en carcinoma mamario de perras.

Palabras claves: citoinclusión, histopatológico, immunohistoquímica, tumor.

\section{INTRODUCTION}

The incidence of mammary neoplasms in female canines and women has been increasing exponentially throughout the world, representing about $20 \%$ of all new cases. Human breast cancer represents $25 \%$ of all neoplasms afflicting humans and mammary tumors have the highest incidence among the neoplasms afflicting female canines, representing $50 \%$ of all neoplasms, with $45 \%$ to $50 \%$ of those tumors being malignant (Misdorp et al 1999, Cassali, 2011, Siegel et al 2012, Terra et al 2012, Inca 2011).

Accepted: 05.01.2017.

aDepartment of Pathology, Botucatu Medical School, Universidade Estadual Paulista, São Paulo, Brazil.

${ }^{b}$ Department of Veterinary Clinics, School of Veterinary Medicine and Animal Science, Universidade Estadual Paulista, São Paulo, Brazil.

${ }^{c}$ Veterinary Pathology Research Group, Faculty of Agricultural Sciences, Universidad de Caldas, Manizales, Colombia; GIDIMEVETZ, Universidad Pedagógica y Tecnológica de Colombia, Tunja-Boyacá, Colombia.

${ }^{\mathrm{d} D e p a r t m e n t ~ o f ~ P a t h o l o g y, ~ B a r r e t o s ~ C a n c e r ~ H o s p i t a l ~ a n d ~ F a c u l t y ~ o f ~}$ Health Sciences Barretos Dr Paulo Prata, Barretos, Brazil.

*Corresponding author: LM Montoya; maomontoya53@yahoo.es
The high incidence and the aggressiveness of this disease demanded search for fast, low-cost and less invasive diagnostic methods (Zanoni et al 2013). In this context, the cytology technique has earned a position in the spotlight for offering diagnostic resources in cytomorphological studies, immunohistochemical studies, flow cytometry and molecular biology techniques. It aids in the diagnosis of benignant and malignant ailments in several organs (Zuccari et al 2001, Bueno et al 2013, Ferreira et al 2013), as well as in determining the need of anaesthetising the animal (Zuccari et al 2001).

It is worth mentioning that diagnostic methods widely employed in Human Medicine are still seldom explored in Veterinary Medicine, especially regarding the application of cytoinclusion, or cell block (CB), without the use of agarose (Bueno et al 2013). This method was originally proposed for processing electronic microscopy samples (Mulder et al 1997, Sanchez and Selvaggi 2006) and may potentially optimize the cytological sample by enabling its "blocking" in paraffin for posterior processing, as happens with a histological sample (Zanoni et al 2012). 
This presents several advantages, such as an architectural analysis similar to histopathological examinations (Constantian and Girolami 1973) and molecular tests (Crapanzano et al 2014).

The use of the cell block technique to determine the expression of oestrogen (ER), progesterone (PR) and cytokeratin 5 (CK5) receptors allows a better therapeutic approach (Bueno y col 2013, Zanoni et al 2012; Horta et al 2012). An increased expression for the oestrogen (ER) and progesterone (PR) receptors is related to a better prognosis while the positivity of the CK5 receptor is related to a worse prognosis, in both canines and humans with mammary carcinomas (Terra et al 2012, Horta et al 2012, Figueiroa et al 2012). In canines, the expression of ER is higher in benignant tumors than in malignant ones and is also higher in complex and mixed tumors in comparison with simple sub-types (De Las Mulas et al 2004).

The expression of PR is mediated by ER, and its positivity is considered as a marker for working oestrogen receptors. Around $50 \%$ of all tumors positive for ER are also positive for PR and, among these, around $75 \%$ are sensitive to hormonal therapy. Tumors that are positive for ER and negative for PR are less sensitive to hormonal therapy, suggesting a possible contribution of PR in the response to this treatment. Tumors that are negative for ER and positive for PR have shown an intermediary response to hormonal therapy (Yamashita et al 2006, Zuccari et al 2008).

Myoepithelial cells express cytokeratins specific for base cells, such as CK5, which is part of the cytoskeleton of these cells. Located in the basal and parabasal layers, as well as in mammary progenitor cells, which have the ability to differentiate in glandular and myoepithelial cells, the expression of the CK5 gene is related to a worse prognosis both in canines and humans. In the latter, it is related to the basal phenotype, which has the worst prognosis (Figueiroa et al 2012, Matos et al 2005).

This study aims at determining the degree of correlation between the immunohistochemical marking for the ER, PR and CK5 receptors in the cytoinclusion and histopathological techniques in the diagnosis of canine mammary carcinoma, as well as in diagnoses by cytoinclusion and in the morphological diagnosis of the surgical specimen in order to verify the sensitivity of the method.

\section{MATERIAL AND METHODS}

\section{SAMPLES}

Samples were collected from 25 female dogs that were at least 5 years old, without bias for any breeds. These dogs presented a definitive diagnosis of mammary carcinoma and their owners sought treatment in the Veterinary Hospital of the College for Veterinary Medicine and Animal Sciences (FMVZ-Faculdade de Medicina Veterinária e Zootecnia) of the São Paulo State University (UNESP), Botucatu campus.
The Brazilian Ethics Commission in the Use of Animals (protocol no. 119/2014-ECUA) approved the study and the owners of all animals involved in the study signed a Free and Clarified Consent Term authorising the collection of material and the use of the data in research papers.

Cytological, histopathological and immunohistochemical studies were conducted in the Veterinary Pathology Laboratory, in collaboration with the Pathology Laboratory of the Botucatu Medicine College-UNESP.

\section{CELL BLOCK TECHNIQUE AND MORPHOLOGICAL} ANALYSIS

The animals underwent radical or unilateral mastectomy, as well as hysterectomy, salpingectomy and oophorectomy. After surgical removal, the cell block technique was conducted in a fresh piece. According to the pilot test conducted, there were no differences in the quality of the material obtained regarding size of the dog and before or after surgery.

According on the size of the wound, the piece was punctured with a 22 to 26 gauge needle in a $10 \mathrm{~mL} \mathrm{BD}$ syringe (Cameco, London, UK) connected to the valeri cytology-aspirator ${ }^{\circledR}$ (MPJ Equipamentos Médicos) until a minimum amount of $0.1 \mathrm{~mL}$ was obtained per animal. In each case, the samples were dried at room temperature and then fixed in $100 \%$ methanol for later application of the rapid Romanowsky stain (Diffi Quick) and Giemsa stain (Raskin and Meyer 2010).

For the cell block, the material in the needle and syringe was initially fixed in $2 \mathrm{~mL}$ of $95 \%$ alcohol for 30 seconds for cohesion, and then by the aspiration of $8.0 \mathrm{~mL}$ of $7.4 \%$ buffered formalin solution. The sample remained inside the syringe for fixation during 24 hours. After the material was removed with the aid of anatomical tweezers, it remained for 30 minutes in alcoholic-eosin and then underwent histotechnical processing and staining through the Hematoxylin-Eosin (HE) technique, i.e. inclusion in a paraffin cassette, $4 \mu \mathrm{m}$ microtomy and staining battery.

The cytomorphological analysis through HE staining was conducted independently by two veterinary pathologists in an optical microscope (Zeiss Axio Lab.A1). For each slide, 10 fields were read with 400x magnification. The neoplasms were classified according to the criteria established by Zakhour and Wells (1999) and Raskin and Meyer (2010) regarding cellular composition. Inter-observer variation was resolved by simultaneous dual re-evaluation.

The smears, the cytoinclusion slides and the surgical piece slides were analysed separately, so that the pathologists could not identify the corresponding slides.

\section{HISTOPATHOLOGICAL CLASSIFICATION}

In each case, samples were collected and fixed in $10 \%$ neutral buffered formalin solution. Tissue samples were 
processed routinely, embedded in paraffin wax and sectioned for Hematoxylin-eosin (HE) staining. Tumor classification was defined according to the WHO classification (Misdorp et al 1999) and the grading systems for canine mammary tumors (Goldschmidt et al 2011).

The criteria of malignancy was based in the presence of cells with enlarged nuclei and prominent nucleoli, according with: tumor type, significant nuclear and cellular pleomorphism, mitotic index, presence of randomly distributed areas of necrosis within the neoplasm, peritumoral and lymphatic invasion, and regional lymph node metastasis (Goldschmidt et al 2011).

Tumor sections were examined in an optical microscope (Zeiss Axio Lab.A1) by two veterinary pathologists. For each slide, 10 fields were read with 400x magnification. Inter-observer variation was resolved by simultaneous dual re-evaluation.

\section{IMMUNOHISTOCHEMICAL STUDY}

Serial sections $4 \mu \mathrm{m}$ thick were cut from each block and placed in Slidetech Plus Novocastra ${ }^{\circledR}$ Newcastle UK glass slides. After deparaffinisation in xylene, the slides were rehydrated and washed in Tris Buffered Saline (TBS). The endogenous peroxidase activity was quenched by a 10-minute incubation in a mixture of $3 \%$ hydrogen peroxide solution in $100 \%$ methanol (Sigma). The antigen retrieval was conducted with citrate buffer (pH 6.0) in a pascal pressure cooker. Slides were cleared with TBS and placed at room temperature for 1 hour. They were then incubated with antibodies for ER (LH2 clone, dilution 1:40, Novocastra, UK), PR (SP2 clone, dilution 1:50, Neomarkers, USA) and CK5 (clone XM26, dilution 1:50, Neomarkers, USA) overnight at $+8^{\circ} \mathrm{C}$. The signal was visualised using the DAKO-EnVision Kit (k 5007 HRP Rabbit/Mouse) according to the instructions of the manufacturer. After washing with TBS, slides were kept in diaminobenzidine tetrahydrochloride for $7 \mathrm{~min}$ then counter-stained with Mayers hematoxylin.

We conducted a comparative analysis for the ER and CK5 markings in the cytoinclusion slides and in the surgical piece slides. We considered positive cases those in which ER and PR presented nuclear marking exceeding $1 \%$ (Hammond et al 2010), and those in which the cytoplasmic marking of CK5 presented immunopositivity exceeding $10 \%$ (Ramalho et al 2006).

For CK5, we considered positive cases with two crosses $(2+)$ when, at most, $50 \%$ of the neoplastic cells presented marking and positive cases with three crosses $(3+)$ when more than $50 \%$ of the neoplastic cells presented marking (Ramalho et al 2006).

The negative control was conducted for all antibodies by omitting the antibody and as positive control we employed internal and external controls, as parameters for the reactions, with the internal control represented by the non-tumoral mammary glands in the surgical pieces.
The validity of the CB method through immunohistochemical marking was determined through the assessment of sensitivity, specificity, positive predictive value (PPV) and negative predictive value (NPV). For ER and PR, cases with marking in more than $1 \%$ of the neoplastic cells were considered positive, while for CK5, markings in more than $10 \%$ of the neoplastic cells were considered positive, as observed in table 1 .

\section{STATISTICAL ANALYSIS}

The concordance between the histopathological assay, the cytoinclusion and immunohistochemical techniques was assessed by weighted Cohen's Kappa as follows: values $<0$ suggest no concordance; values between $0-0.20$ suggest a slight concordance; $0.21-0.40$ suggest reasonable concordance; 0.41-0.60 moderate concordance; 0.61-0.80 substantial concordance; $0.81-1$ nearly perfect concordance. Statistical difference was considered when $P \leq 0.05$. The statistical analysis was conducted using the software IBM SPSS 20.

\section{RESULTS}

A total of 25 samples of mammary carcinoma were analysed in this study from animals aged between 5 and 15, averaging 9.92 years old. Small, medium and large size animals represented $48 \%, 32 \%$ and $20 \%$ of the cases respectively, with an average weight of $10 \mathrm{~kg}$. The average development period of the tumors was 11.32 months, with an average deviation of 7.28.

\section{HISTOPATHOLOGICAL AND CYTOINCLUSION CLASSIFICATION}

Regarding the histopathological classification, $48 \%$ were carcinomas with mixed tumors, $28 \%$ were tubulopapillary carcinomas and $24 \%$ were complex carcinomas.

There was a high correlation between the morphology of the surgical piece (figure 1) and the cytomorphology of the cytoinclusion assay (figure 2 ), with $100 \%$ concordance

Table 1. Samples considered positive in the immunohistochemical marking in neoplastic cells above $1 \%$ for RE and RP and above $10 \%$ for CK5.

\begin{tabular}{lcc}
\hline & Cytoinclusion (\%) & Surgical Piece (\%) \\
\hline RE & 24 & 24 \\
RP & 84 & 88 \\
CK5 & 92 & 92 \\
& ++40 & ++48 \\
& +++52 & +++44 \\
\hline
\end{tabular}

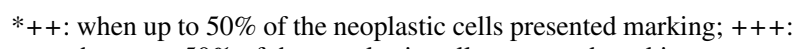
when over $50 \%$ of the neoplastic cells presented marking. 


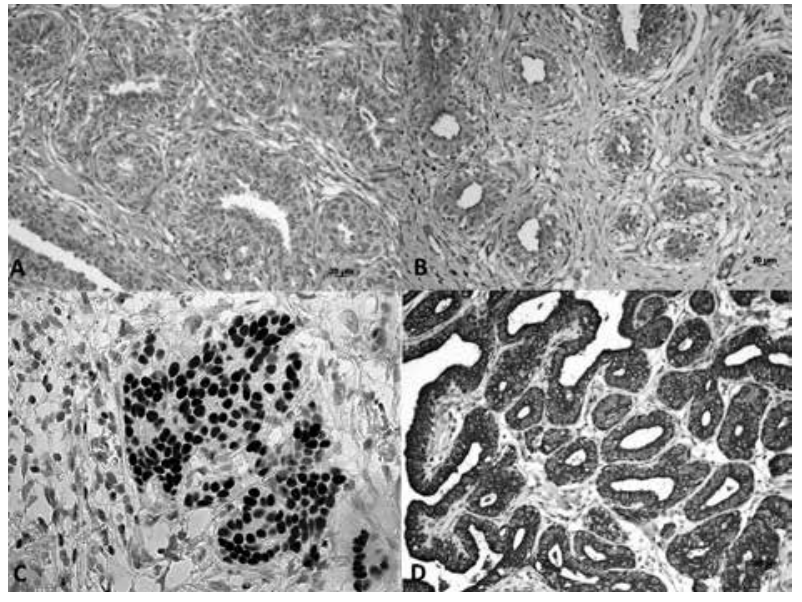

Figure 1. Sample from the surgical piece taken from Animal 3, stained through HE (A), positive marking for RE (B), positive marking for RP (C) and (+++) marking for CK5 (D). Obj. 20X, bar $20 \mu \mathrm{m}$.

between the histopathological assay and the cytoinclusion technique. The same is true for the positivity found in both methods for the oestrogen, progesterone and cytokeratin 5 receptors.

The CB marking for ER presented sensitivity of $85.71 \%$ and specificity of $100 \%, 100 \%$ PPV and $94.74 \%$ NPV. The accuracy was $96 \%$ with a Kappa index of 0.78 and $P<0.01$.

PR presented a sensitivity of $95.45 \%$, specificity of $100 \%, 100 \%$ PPV and $75 \%$ NPV. The accuracy was $96 \%$ with a Kappa index of 0.84 and $P<0.01$.

The CK5 analysis presented $100 \%$ sensitivity, specificity, PPV, NPV and accuracy, with a Kappa index of 0.95 and $P<0.01$.

Finally, in one case (sample 08) the marking was positive for ER in the cytoinclusion assay and negative in the surgical piece assay. In another (sample 25), the marking was considered negative for both ER and PR in the cytoinclusion assay. In two cases (samples 10 and $21)$, CK5 was rated $3+$ in the cytoinclusion assay and $2+$ in the surgical piece assay.

\section{DISCUSSION}

Cytoinclusion has been used in human medicine for over 50 years, gaining strength towards the end of the 1990s and beginning of the 2000s due to the simplification of the technique, which no longer required the use of agarose (Bueno et al 2013). The method is reliable and may be used for screening patients, assessing predictive factors and prognoses related to these markers, as well as presenting reduced costs due to requiring fewer materials.

In this study, the technique provided enough material for conducting smear and cytoinclusion assays, enabling the diagnosis of the neoplasm and the research regarding the oestrogen, progesterone and cytokeratin 5 receptors,

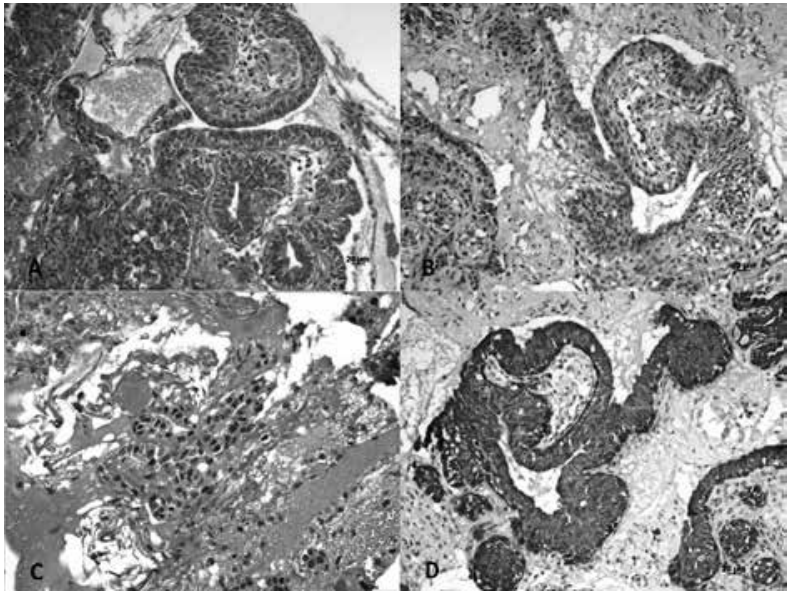

Figure 2. Sample from the cytoinclusion assay taken from Animal 3, stained through HE (A), positive marking for RE (B), positive marking for RP (C), positive (+++) marking for CK5

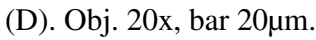

confirming the ease and quickness this technique presents in the collection of material.

As happens in human females, the verification of positivity for immunohistochemical markers enables the application of neoadjuvant chemotherapy with an adequate choice of chemotherapeutic agents, which makes subsequent surgical procedures less complicated, reducing costs and improving the prognosis (Nguyen et al 2011).

The high correlation between the morphology of the surgical piece and the cytomorphology of the cytoinclusion assay, together with the positivity found in cytoinclusions conducted in this study for the oestrogen, progesterone and cytokeratin 5 receptors, is in accordance with the percentages found for surgical pieces in the literature regarding mammary tumors (Figueiroa et al 2012). The results are also similar to those reached by Bueno et al (2013) in a comparative study between cytoinclusion and surgical specimen of mammary tumors in women. According Fowler and Lachar (2008), who describes the quality of immunostaining in the cell block sections, it is identical to that of paraffin embedded tissue fixed in formalin.

The literature regarding the use of cytoinclusion in veterinary medicine is scarce. Zanoni et al (2012), in a comparative study between the cell block technique in agarose and smears of canine mammary tumors, found diagnostic concordance levels of $13.7 \%$ and $5.9 \%$, respectively, in comparison with the surgical piece, showing a better representativeness of the CB technique.

Paiva et al $\left(2011^{\mathrm{a}}\right)$ compared the cytological assay and cytoinclusion in 12 neoplasms, reaching concordance in $58.3 \%$ of the cases. In all cases, an immunohistochemical assay for cytokeratin and vimentin confirmed the histological origin.

In this study, the high degree of correlation between the surgical specimen and the cytoinclusion technique 
is in accordance with the figures found by Bueno et al (2013), whose samples obtained by cytoinclusion provide a material with high cellularity and representativeness of the wound, enabling the correlation between techniques.

Furthermore, the prevalence of carcinoma-mixed type, tubulopapillary carcinoma and carcinoma-complex type in our results is in accordance with other studies in mammary female dogs that describe carcinomas and malignant mixed tumors as the most frequent tumors, in addition to benign cases. However, these numbers have considerably variations due to the different methods of classifying tumors, especially the separation of mixed tumors and carcinomas (Else and Hannant 1979, Moulton 1990). Comparing with recent studies in female dogs, the prevalence of papillary carcinoma was observed by Kamiguchi et al (2016).

A recent consensus issued by the College of American Pathologists, the International Association for the Study of Lung Cancer and the Association for Molecular Pathology recommends the cytoinclusion technique for EGFR immunohistochemical assay for lung cancer (Lindeman et al 2013).

The use of IHC during the cytoinclusion technique has shown better results in comparison to smears, presenting a lower amount of artifacts and false-positives, as well as a good correlation with the findings in the surgical specimen (Bueno et al 2013).

In cases with differences in the markings, it is important to consider the heterogeneous morphology of mammary tumors. A single sample often presents areas with varying appearances, hyperplastic sites parallel to neoplastic nodules and mixed-pattern areas (Zanoni et al 2013). Therefore, it is possible that the marking and score differences of some samples are caused by this situation.

Another aspect to be considered is the presence of necrosis in the cytological sample, which interferes both with the diagnosis of the neoplasm and with the immunohistochemical assays (Paiva et al 2011 $1^{\mathrm{b}}$ ), as observed in a false negative case for the ER and PR markers. This highlights the importance of understanding the technique during the collection of samples.

Therefore, based on the results reached by this study, we suggest the use of this diagnostic technique in the practice of Veterinary Medicine. The high sensitivity found for the immunohistochemical marking of ER, PR and CK5, in addition to the high correlation between the cytomorphological diagnosis through cytoinclusion and the morphological diagnosis through the surgical specimen, makes it plausible to state that cytoinclusion is as efficient in veterinary medicine as in human medicine. Thus, it represents a safe and low-cost method for the study of prognostic markers with CB.

\section{ACKNOWLEDGEMENTS}

The authors would like to thank the Fundação de Amparo à Pesquisa do Estado de São Paulo (FAPESP) for its financial support in the development of this project. This sponsor did not have any influence over the study design, over the collection, analysis and interpretation of data, or over the writing of the manuscript and the subsequent decision to submit it for publication. Proc 10/51596-2R.

\section{REFERENCES}

Bueno AS, Viero RM, Soares CT. 2013. Fine needle aspirate cell blocks are reliable for detection of hormone receptors and HER-2 by immunohistochemistry in breast carcinoma. Cytopathology 24, 26-32.

Cassali GD. 2011. Consensus for the diagnosis, prognosis and treatment of canine mammary tumors. Braz J Vet Pathol 4, 153-180.

Constantian HM, de Girolami E. 1973. Urothelial tumors detected by cytology: New cell block technique. J Urol 109, 304-307.

Crapanzano JP, Heymann JJ, Monaco S, Nassar A, Saqi A. 2014. The state of cell block variation and satisfaction in the era of molecular diagnostics and personalized medicine. Cyto Journal, 11-17.

De Las Mulas JM, Ordás J, Millán MY, Chacón F, De Lara M, et al. 2004. Immunohistochemical expression of estrogen receptor $\beta$ in normal and tumoral canine mammary glands. Vet Pathol 41, 269-272.

Else RW, Hannant D. 1979. Some epidemiological aspects of mammary neoplasia in the bitch. Vet Rec 104, 296-304.

Ferreira I, Bulla C, Baumgartner W, Bagnato VS, Rocha NS. 2013. Quantitative analysis of photodynamic therapy effects in rat mammary tumor vascular density using Image-Pro Plus Software. Open Journal of Veterinary Medicine 3, 259-262.

Figueiroa FC, Salgado BS, Monteiro LN, Rocha RM, Domingues MAC, et al. 2012. Immunoexpression of cathepsin $\mathrm{D}$ and $\mathrm{S} 100 \mathrm{~A} 4$ protein and their molecular subtyptes in canine mammary carcinomas. Open Journal of Veterinary Medicine 2, 163-169.

Fowler LJ, Lachar WA. 2008. Application of immunohistochemistry to cytology. Arch Pathol Lab Med 132, 373-83.

Goldschmidt M, Peña L, Rasotto R, Zappulli V. 2011. Classification and grading of canine mammary tumors. Vet Pathol 48, 117-131.

Hammond ME, Hayes DF, Dowsett M, Allred DC, Hagerty KL, et al. 2010. American Society of Clinical Oncology/College of American Pathologists Guideline Recommendations for Immunohistochemical Testing of Estrogen and Progesterone Receptors in Breast Cancer (Unabridged Version). Arch Pathol Lab Med 134, 48-72.

Horta RS, Costa MP, Lavalle GE, Araújo RB, Cassali GD. 2012. Fatores prognósticos e preditivos dos tumores caninos definidos com o auxílio da imuno-histoquímica. Cienc Rural 42, 1033-1039.

INCA-Brasil (Instituto Nacional do Câncer). 2011. Cancer incidence in Brazil estimate/2012. INCA, Rio de Janeiro, Brazil.

Kamiguchi IE, Moreira IM, Da Silva Trindade F, Zahn FS, Hataka A, et al. 2016. Mammary neoplasms in female dogs: Identification of cytopathological criteria for malignancy. J Cytol Histol 7, 392.

Lindeman NI, Cagle PT, Beasley MB, Chitale DA, Dacic A, et al. 2013. Molecular testing guideline for selection of lung cancer patients for EGFR and ALK tyrosine kinase inhibitors: guideline from the College of American Pathologists, International Association for the Study of Lung Cancer, and Association for Molecular Pathology. $J$ Thorac Oncol 8, 823-859.

Matos I, Dufloth R, Alvarenga M, Zeferino LC, Schmitt F. 2005. p63, cytokeratin 5, and P-cadherin: three molecular markers to distinguish basal phenotype in breast carcinomas. Virchows Archiv 447, 688-694.

Misdorp W, Else RW, Hellmén E, Lipscomb TP. 1999. Histological classification of the mammary tumours of the dog and the cat. In: World Health Organization. International histological classification of tumours of domestic animals. $2^{\text {nd }}$ series. Vol.7. Washington, DC, USA, Pp 59.

Moulton JE. 1990. Tumors of the mammary gland. In: Moulton JE (ed). Tumors in domestic animals. University of California Press, Los Angeles, Pp 518-552.

Mulder AB, Blom NR, van der Meer J, Ruud HM, Smit JW. 1997. A simple procedure for in situ immunolabeling embedding and sectioning of 
layers of cultured endothelial and smooth muscle cells for both light and electron microscopy. Biotech Histochem 72, 45-48.

Nguyen F, Abadie J, Loussouarn D, Ibisch C, Rieder N, et al. 2011. Spontaneous canine mammary carcinomas as a model of human triple-negative breast câncer. Cancer Res ( 8 Supplement) 71, LB-46.

Paiva MB, Gouveia GM, Beserra HEO, Silva JM, Luvizotto MCR. 2011 ${ }^{\mathrm{a}}$ Use of cellblock method for neoplastic diagnosis in veterinary medicine. In: Anais do XV Encontro Nacional de Patologia Veterinária (ENAPAVE), Goiânia, Brazil.

Paiva MB, Gouveia GM, Luvizotto MCR. 2011 ${ }^{\text {b }}$. Utilização de marcador orgânico na técnica de cito inclusão com gel de agarose. Vet Zootec 18, 76.

Ramalho LNZ, Ribeiro-Silva A, Cassali GD, Zucoloto S. 2006. The expression of p63 and cytokeratin 5 in mixed tumors of the canine mammary gland provides new insights into the histogenesis of these neoplasms. Vet Pathol 43, 424-429.

Raskin RE, Meyer DJ. 2010. Atlas de Citologia de Cães e Gatos. $1^{\text {st }}$ ed. Ed Rocca, São Paulo, Brasil.

Sanchez N, Selvaggi SM. 2006. Utility of cell blocks in the diagnosis of thyroid aspirates diagnostic. Cytopathology 34, 89-92.

Siegel R, Naishadham D, Jemal A. 2012. Cancer statistics-CA-Cancer. J Clin 62, 10-29.
Terra EM, Rodrigues MP, Magalhães GM, Costa MT, Amorim RL, et al. 2012. Immunohistochemical expression of p53 and p63 in adenomas and carcinomas of canine mammary glands. OJVM 2, 21-24.

Yamashita H, Yando Y, Nishio M, Zhang Z, Hamaguchi M, et al. 2006. Immunohistochemical evaluation of hormone receptor status for predicting response to endocrine therapy in metastatic breast cancer. Breast Cancer 13, 74-83.

Zakhour H, Wells C. 1999. Diagnostic cytopathology of the breast. Churchill Livingstone, London, UK.

Zanoni DS, Grandi F, Rocha NS. 2012. Use of the agarose cell block technique in veterinary diagnostic cytopathology: an "old and forgotten" method. Vet Clin Pathol 41, 307-310.

Zanoni DS, Kleeb SR, Xavier JG. 2013. Employment of cell block of agarose as additional method in the cytological diagnosis of canine mammary tumors. Cienc Rural 43, 489-495.

Zuccari DAPC, Santana AE, Rocha NS. 2001. Correlação entre a citologia aspirativa por agulha fina e a histologia no diagnóstico de tumores mamários de cadelas. Braz J Vet Res Anim Sci 38, 38-41.

Zuccari DAPC, Berton CR, Terzian ACB, Ruiz CM. 2008. Fatores prognósticos e preditivos nas neoplasias mamárias-importância dos marcadores imuno-histoquímicos nas espécies humana e canina-estudo comparativo. Arq Ciênc Saúde 15, 189-198. 